\title{
Consumers' Perspective for the Betterment of Street Food and Women Food Vendors in Kolkata
}

\author{
Parvin Anjum Wara, Nayak Binata \\ Department of Home Science, University of Calcutta, Kolkata, India \\ Email address: \\ Anjum1988@yahoo.com (P. A. Wara),Binata_nayak@yahoo.com (N. Binata)
}

\section{To cite this article:}

Parvin Anjum Wara, Nayak Binata. Consumers' Perspective for the Betterment of Street Food and Women Food Vendors in Kolkata. International Journal of Nutrition and Food Sciences. Vol. 10, No. 4, 2021, pp. 89-94. doi: 10.11648/j.ijnfs.20211004.13

Received: August 10, 2021; Accepted: August 23, 2021; Published: August 30, 2021

\begin{abstract}
Like all other city of India, street foods are widely used in Kolkata. Without any formal establishment street food mainly comprises unorganized food vending where cooked food may be served. Street foods are easily available and affordable to consumers, so it is highly popular to all age group specially in urban area. The objective of the study was to assess the socioeconomic status, food safety knowledge and attitude among street food consumers. To find out the status of street food consumers and their perspective for the betterment of street food and women food vendor a questionnaire was given to 65 consumers. The data found that $27.7 \%$ consumers take street food daily basis, $35.4 \%$ choose women vendor for neat and clean stall. Among all street food stable foods (like rice, roti) are most popular. $56.9 \%$ people take street food for easy availability. $21.5 \%$ consumers had no idea about food borne illness. There are large number of women street food vendors are selling cooked food in Kolkata. There are also many consumer depends on street foods only. However they all want betterment of street food, betterment of women food vendor and they suggest social security, good infrastructure, and training programme for vendor. To satisfy consumer demand for street foods change in existing perception and government supervision is necessary.
\end{abstract}

Keywords: Street Food, Women Food Vendor, Street Food Consumers, Food Safety Knowledge, Social Security

\section{Introduction}

'Street foods' are define as the ready to eat foods or beverages prepare and sold by vendors in street or other public places without any structured shop and the food is ready for immediate consumption [7]. The popularity of street food increases rapidly due to industrial development and increase in urban population [8].

Women street vendors are contributing a positive effect to our society. They have chosen street vending as the source of their livelihood as they wanted to help their family financially. Women are often owner or employee of street food business. According to FAO 70- 90\% vendors are women and they sell food in the street to improve their financial independence. (FAO, 1997) [10].

Street foods are accepted by a vast number of city-dwellers as it is usually inexpensive, convenient and often nutritious too [1]. It contribute significantly to the diet of people belongs to low and middle income group [2, 12]. In recent times the foremost consumption of street food has became a habit to the city people. It has indicated that more consumers are stayed a long time out side their home and that is why they eat more meals $[3,11]$. This prevalent consumption needs the importance of food safety [4].

The affordability and easy accessibility of street food make it highly popular across all age groups of city people.) Despite having many benefits street vended foods often have some risk to health of consumers if not prepare or served hygienically $[1,13,14]$. Consumers are sometimes unaware about food safety and food-borne diseases [9]. Some consumers are sensitive about the need of food and sometimes they have a role decision making process $[3,5]$.

Although the FAO and WHO applied some rules to ensure the safety of street foods. Many studies has shown that there is no legal arrangement for food safety in many cities all over the world [4]. Like many countries of the world there is is a rapid increase in purchasing and consumption of street food in India as well as Kolkata is become a trends now-a-days. The hygiene and sanitation always been a matter of concern in preparation and serving of street foods. More over women street food vendors are usually faced infrastructure problem 
like lack of running water, inappropriate space for vending, lace of sanitary toilet facility etc $[6,15]$.

However, there has not been a appropriate study on this subject in Kolkata. Therefore this study was planned and carried out in order to determine the street food and women food vendors preferences, the reason for this preferences and socio-economic status of street food consumers and their suggestion towards healthy street foods and betterment of women street food vendors.

\section{Methodology}

\subsection{Study Design}

The survey was conducted by Random sampling method in five zone of Kolkata i.e south, north, east, west and central Kolkata. The data were collected in the month of June to September, 2019.

\subsection{Instrumentation}

The data were collected for the research through a questionnaire. The questionnaire was prepared by the researches own. To test the accuracy of the questionnaire pilot study was done on 30 consumers then suitable modification were done. The questionnaire was prepared by the researches own. The consumer included who are only consuming from women vendor. Informed consent was obtained from all participants.

\subsection{Data Collection Method}

The data were collected by the researcher by own by face to face interview method. The questionnaire includes socioeconomic data, purchasing habits, consumption preferences, knowledge about food safety and view about women street food vendors, opinion about safe street food and improvement of women street food vendors.

\subsection{Ethical Approval}

The research received ethical approval from the university of Calcutta Ethics committee (Research project: Nutritional and food safety issues concerning street foods from women vendors and their contribution to the diet of people in Kolkata) with ref.no. 07/ST/20-21/1772 dated 27.02.2020.

\subsection{Demographic Information}

The first section of the questionnaire was 6 question related to gender, marital status, occupation, no. of family member, educational qualification, food habit etc.

\subsection{Food and Vendor Related Questions}

There are 20 more question related to street food, knowledge about street food, concept about food safety and opinion about women vendors, view about street food vending, healthy food etc. This section include 20 independent multiple choice questions.

\subsection{Statistical Analysis}

Data entering was done by researchers and was checked twice to ensure quality control and corrected accordingly. Preliminary data was entered into Microsoft access 2010 and after quality check it were exported into Microsoft Excel 2010. For all analysis of data were done by SPSS version 23.0 and MS Excel statistical software packages. The result were expressed as frequency and percentage. A group statistics was done using total scores of male and female consumers with their mean, standard deviation and t-value were determined.

Table 1. Socio-Demographic status of consumer.

\begin{tabular}{llll}
\hline Variables & category & Frequency & percentage \\
\hline Sex & Male & 51 & 78.5 \\
& Female & 14 & 21.5 \\
occupation & 1 & 21 & 32.3 \\
& 2 & 12 & 18.5 \\
& 3 & 13 & 20.0 \\
marital status & 4 & 19 & 29.2 \\
no. of family members & Married & 43 & 66.2 \\
& Unmarried & 22 & 33.8 \\
& 1 & 2 & 3.1 \\
& $2-4$ & 40 & 61.5 \\
education qualification & 5-7 & 22 & 33.8 \\
& $>7$ & 1 & 1.5 \\
& Illiterate & 4 & 6.2 \\
& Pre-primary & 5 & 7.7 \\
& Primary & 6 & 9.2 \\
& Madhyamik & 10 & 15.4 \\
& Higher Secondary & 15 & 23.1 \\
& Graduate & 17 & 26.2 \\
food habits & Post graduate & 8 & 12.3 \\
& Veg & 2 & 3.1 \\
& Non-veg & 63 & 96.9 \\
\hline \multirow{5}{*}{ mats } & &
\end{tabular}

\section{Result and Discussion}

\subsection{Socio Demographic Result}

The table 1 shows the socio demographic data. A total 65 consumers were interviewed, among them $78.5 \%$ (51) are male and $21.5 \%$ (14) are female. This data indicates most ofconsumers are male. A previous study shows that among all consumer $43.4 \%$ were male and $56.6 \%$ were female; majority of them were between 19-22 years age [4]. Among them $66.2 \%$ (43) are married and $33.8 \%$ (22) are unmarried. By occupation $32.3 \%$ have business, 18.55 service man, $20 \%$ student and $29.2 \%$ doing other job (like sales man, labor etc). It indicates consumers are from all occupation they are not belongs to any particular sector. Only $2 \%$ (3) consumers' family member is one, most of them $61.5 \%$ (40) have 2-4 family member. $33.8 \%$ (22) consumers have 5-7 family member. Only $1.5 \%$ (1) consumers' family member was greater than 7 . Only $12.3 \%$ (8) consumer have post graduation, $26.2 \%$ (17) were graduate, $23.1 \%$ (15) have higher secondary education. $15.5 \%$ (10) were Madhyamik. $9.2 \%$ (6) were primary. $7.7 \%$ (5) were pre-primary and $6.2 \%$ (4) are illiterate. This data proved that both higher and lower educated consumers prefer street food for their 
livelihood. A another study shows that most consumers were male, single and had some high school education or matriculated. [2]

Among them only $3.1 \%$ (2) are vegetarian and all others are $96.9 \%$ (63) are non-vegetarian. Thatindicatesmost of street food consumers are non-vegetarian.

\subsection{Consumers'Attitude, Preference and View}

There were 20 variables in Table 2. The data shows consumers attitude, food preferences and view about betterment of street food and women street food vendors. The data shows $35.4 \%$ (23) consumer cannot bring food from home that's why they eat outside and $33.8 \%$ (22) consumers replied that they have to stay long time outside home. $56.9 \%$ (37) prefers street food because of its easy availability. Among all consumer 27.7\% (18) eats street food 3-4 times in a week. And 27.7\% (18) eats street food everyday. 26.2\% eats occasionally. $46.2 \%$ (30) consumer eats once in a day, $27.7 \%$ (18) eats two or three times in a day. Only $3.8 \%$ eats more than three times a day. The above data indicates many people depends totally on street foods when they stay out side the home. Where as the previous study shows that $68.4 \%$ respondent were carrying lunch with them and $54.6 \%$ prefer street food. [1]. Most consumer (47.7\%) prefer stable food like rice, roti etc. Whereas $29.2 \%$ prefer fast food like roll, chowmin etc. Only $13.8 \%$ prefer tea or coffee as street food. This data indicates that tea or coffee is common but most of the people prefer stable food because it keeps stomach full for long time. $49.2 \%$ (32) consumer prefer neat and clean stall whereas $33.8 \%$ (22) has not any preferences. $13.8 \%$ search for tasty food and only $3.8 \%$ eat at renowned shop. The data shows $53.8 \%$ (35) eat to women vendor for nothing special reason. Whereas $35.4 \%$ (23) eat for neat and clean stall. Only $7.7 \%$ (5) consumers' view that they provide tasty food. Some consumer think that women vendors keep their stall more clean than male and some consumers think women vendors provide more tasty foods.

If the food quality is good $30.8 \%$ (20) consumer eat from same vendor everyday. Whereas $32.3 \%$ (21) shift everyday. Food preferences depends on food quality, if the quality is good food preferences increases. Some people have to shifted everyday because of their job types that's why they can eat everyday from same vendors. According to 30.8\% (20) consumers' view rice/roti were most popular street food. Whereas $26.2 \%$ (17) said fast food is most popular. $73.8 \%$
(48) consumer prefers food in hot condition. Whereas only $6.2 \%$ prefer cold food. It seems that they have the knowledge that hot foods are microbiologically safe than cold food that's why they always prefer hot food.. Most of consumer (89.2\%) never fall ill from street food, only $10.8 \%$ fall ill like diarrhea $(436 \%)$, stomach infection $(6.2 \%)$ and vomiting $(1.5 \%)$. From that data it can conclude that street foods are not always harm-full.

About $21.5 \%$ (14) are not concerned about food borne illness whereas $24.6 \%$ (16) have not any idea about it. $53.8 \%$ (35) is aware about food borne illness. This data indicates most of consumers are aware about food-borne illness. A previous study shows that $65.4 \%$ consumer had awareness whereas $58 \%$ were unaware about food borne disease [1]. $63.1 \%(41)$ consumers are satisfied with the cleanliness of the vendor and $16.9 \%$ (11) are not satisfied with the cleanliness. $83.1 \%$ (54) consumer thinks that hand washing is mandatory before serving food whereas $7.7 \%$ (5) thinks that is not mandatory and $9.2 \%$ (6) have no idea about it. It indicates some consumers are not aware about food safety. $56.9 \%$ (37) consumer wants to stop food vending during infectious diseases whereas $9.2 \%$ (6) does not think so. Clean water source is important to $44.6 \%$ (26) consumer for street food vending, $13.8 \%$ (9) wants dust protected stall, $1.5 \%$ (1) consumer wants apron and cap for vendor. 40\% (26) wants all the above parameters. All the parameters are important but some of them are not think so. That's why they choose only one or two parameters. For good food preparation 12.3\% (8) wants stop adulteration, $12.3 \%$ (8) wants fresh ingredients, $3.1 \%$ (2) wants preparation of nutritious food and $41.5 \%$ (27) wants all the parameter for good street food preparations. Here also all parameters are important for good food preparation, bu some of them choose only one that indicates lack of knowledge.

$18.5 \%$ (12) of consumer wants arrangement of training program for women vendor, $18.5 \%$ (12) wants financial help and $18.5 \%$ (12) wants social security to encourage women empowerment whereas $44.6 \%$ (29) wants all the above support for women vendor. All of them think that street vendors need support. From the above discussion it come to know that some street food consumers need more aware about food safety. Women vendors need government and social support to improve their business. If they get support from others they can provide more safe foods for consumers.

Table 2. Frequency \& percentage distribution of consumer Attitude, preferences etc.

\begin{tabular}{|c|c|c|c|}
\hline Variables & category & Frequency & Percentage \\
\hline \multirow[t]{3}{*}{ why you eat outside? } & Stay long time from Home & 22 & 33.8 \\
\hline & Impossible to bring food from Home & 23 & 35.4 \\
\hline & Like to take food with friends & 7 & 10.8 \\
\hline \multirow[t]{4}{*}{ Why do you eat street food? } & Inexpensive & 9 & 13.8 \\
\hline & Easily available & 37 & 56.9 \\
\hline & More tasty & 10 & 15.4 \\
\hline & Less time consumable & 9 & 13.8 \\
\hline
\end{tabular}




\begin{tabular}{|c|c|c|c|}
\hline Variables & category & Frequency & Percentage \\
\hline \multirow[t]{4}{*}{ how often do you eat street foods? } & 1 to 2 times in a week & 12 & 18.5 \\
\hline & 3 to 4 times in a week & 18 & 27.7 \\
\hline & Everyday & 18 & 27.7 \\
\hline & Occasionally & 17 & 26.2 \\
\hline \multirow[t]{4}{*}{ How many times do you take street food in a day? } & Once in a day & 30 & 46.2 \\
\hline & Two to Three times in a day & 18 & 27.7 \\
\hline & More than Three Times & 2 & 3.1 \\
\hline & Varies day to day & 15 & 23.1 \\
\hline \multirow[t]{4}{*}{ What types of food do you prefer? } & Rice/Roti etc. & 31 & 47.7 \\
\hline & Fast food (Roll/Chowmin) & 19 & 29.2 \\
\hline & Fried food (Fried cake/ pakora) & 6 & 9.2 \\
\hline & Tea or coffee & 9 & 13.8 \\
\hline \multicolumn{4}{|l|}{ What types of stalldo you choose? } \\
\hline & Which one is available & 22 & 33.8 \\
\hline & Which shop provide tasty food & 9 & 13.8 \\
\hline & Neat and clean stall & 32 & 49.2 \\
\hline & Famous shop & 2 & 3.1 \\
\hline \multicolumn{4}{|l|}{ Why are you choose women food vendor? } \\
\hline & They provide Tasty food & 5 & 7.7 \\
\hline & Their stall is neat \& Clean & 23 & 35.4 \\
\hline & To encourage their business & 2 & 3.1 \\
\hline & Nothing special reason & 35 & 53.8 \\
\hline \multicolumn{4}{|l|}{ Do you eat from same vendor every day? } \\
\hline & Yes, if the food quality is good & 20 & 30.8 \\
\hline & it depends on time & 24 & 36.9 \\
\hline & I shift everyday & 21 & 32.3 \\
\hline \multicolumn{4}{|c|}{ According to you which food is most popular among street food? } \\
\hline & Chowmin (Veg/egg/Chicken) & 17 & 26.2 \\
\hline & * Roll (veg/Egg/Chicken) & 11 & 16.9 \\
\hline & $*$ Ghugni & 2 & 3.1 \\
\hline & * PaoBhaji & 1 & 1.5 \\
\hline & * Fried Cake/Pechora & 5 & 7.7 \\
\hline & Momo (veg/Chicken) & 4 & 6.2 \\
\hline & « Nun puri + ChhanaBatora & 4 & 6.2 \\
\hline & « Rice / Roti ma & 20 & 30.8 \\
\hline & « Egg toast & 1 & 1.5 \\
\hline \multicolumn{4}{|l|}{ Do you prefer the food hot or cold? } \\
\hline & Hot & 48 & 73.8 \\
\hline & $*$ Cold & 4 & 6.2 \\
\hline & « It depends on types of food & 13 & 20.0 \\
\hline \multicolumn{4}{|l|}{ have you fall ill from street foods? } \\
\hline & Never & 58 & 89.2 \\
\hline & $*$ Yes & 7 & 10.8 \\
\hline \multicolumn{4}{|l|}{ What types of illness? } \\
\hline & Diarrhea & 3 & 4.6 \\
\hline & * Jaundice & 0 & 0.0 \\
\hline & * stomach infection & 4 & 6.2 \\
\hline & * Vomiting & 1 & 1.5 \\
\hline & *not having any disease & 57 & 87.7 \\
\hline \multicolumn{4}{|l|}{ How many times do you take food in a day usually? } \\
\hline & In-home & 48 & 73.8 \\
\hline & * Street food & 17 & 26.2 \\
\hline \multicolumn{4}{|l|}{ Do you concern about food borne illness? } \\
\hline & Yes & 35 & 53.8 \\
\hline & * No & 14 & 21.5 \\
\hline & *Ihave noidea & 16 & 24.6 \\
\hline
\end{tabular}




\begin{tabular}{|c|c|c|c|}
\hline Variables & category & Frequency & Percentage \\
\hline \multicolumn{4}{|c|}{ Are you satisfied with the cleanliness of this vendor? } \\
\hline & Yes & 41 & 63.1 \\
\hline & * No & 11 & 16.9 \\
\hline & No Comment & 13 & 20.0 \\
\hline \multicolumn{4}{|c|}{ should street food vendors wash their hands before serving foods? } \\
\hline & Of course, they have to do & 54 & 83.1 \\
\hline & No necessity & 5 & 7.7 \\
\hline & I have no idea & 6 & 9.2 \\
\hline \multicolumn{4}{|c|}{ Should Vendor stop food vending during infectious disease? } \\
\hline & Yes & 37 & 56.9 \\
\hline & $*$ No & 6 & 9.2 \\
\hline & * Nocomment & 22 & 33.8 \\
\hline \multicolumn{4}{|c|}{ Which one is necessary for street vending? } \\
\hline & Clean water source & 29 & 44.6 \\
\hline & * Dust protected stall & 9 & 13.8 \\
\hline & * Vendor have to ware Apron and Cap & 1 & 1.5 \\
\hline & * All the above. & 26 & 40.0 \\
\hline \multicolumn{4}{|c|}{ What advice do you give to vendor for good food preparation? } \\
\hline & Stop food adulteration & 8 & 12.3 \\
\hline & » Use Fresh ingredients & 8 & 12.3 \\
\hline & ‘» Maintain cleanliness & 20 & 30.8 \\
\hline & * prepare nutritious food & 2 & 3.1 \\
\hline & * All the above & 27 & 41.5 \\
\hline \multicolumn{4}{|c|}{ In your opinion what should do by government to encourage women empowerment? } \\
\hline & Arrange training programmer for them & 12 & 18.5 \\
\hline & «By financial helping & 12 & 18.5 \\
\hline & "Give them social security & 12 & 18.5 \\
\hline & $*$ All the above & 29 & 44.6 \\
\hline
\end{tabular}

Table 3 present a group statistics using total scores of male and female consumers with their mean, standard deviation and tvalue. The data shows as follows.

Table 3. Mean, SD and t-test of Customer (Male \& Female).

\begin{tabular}{llllll}
\hline Group Statistics & & & & & \\
\hline & sex & N & Mean & Std. Deviation & t-value \\
\hline Total score & Male & 51 & 46.39 & 5.374 & 0.613 \\
(Customer) & Female & 14 & 45.86 & 6.724 & 0.6 \\
\hline
\end{tabular}

$\mathrm{T}$ (table) value with $63 \mathrm{df}$ at 0.05 level of significance $=1.998$.

Data presented in this table depicted that there is no statistically significant differences in mean values between male \& female customer as the calculated t-value $(0.613)$ is lower than table value of $\mathrm{t}(1.998)$ with 63 dfat 0.05 level of significance. the mean score of male customer is 46.39 and that of female is 45.86 with SD's $5.374 \& 6.724$ respectively.

\section{Conclusion and Recommendation}

The study was conducted to understand the consumers' socio-demographic character, food-safety knowledge, food preferences and view about street food and women food vendors in Kolkata.

The study indicates that many consumers are totally depends on street food during day time. Consumers are choose women vendors mainly for cleanliness.. This also indicates that street foods have the potential to provide consumers to their food and nutritional needs as it is easily accessible, affordable and safe also.

But many of consumers have not any idea about food safety. Even they have not any knowledge about food-borne diseases. The consumers need to be more concern about consequences of food-borne disease which occur due to poor hygiene and negligence in food preparation. Street consumers are belongs to all socio-economic groups and they all want safe street food. They recommended financial support, social security, food safety training for the betterment of street food and women street food vendors.

The findings of the study would help the policy maker to plan many intervention programme for women vendors. It also help them to support women vendor and to assure quality of street food prepare by them. The study suggested the urgent need to support women vendors and to supervise the quality and safety of street food prepared by women 
vendors. This study also suggested the to taking measures when there is the violation of safety which can occur public health risk.

\section{Limitations}

As the sample size of the study was very small and survey was made within a limited time period, the results can't be generalized. Performing the study on a large sample of consumers from women vendors might be more useful.

\section{Acknowledgements}

The authors would like to convey their thanks to all the consumers (sample of the study) who agreed to participate in the study and answered the questions with patience.

\section{References}

[1] Pannu P, Kataria D (2016) Consumer perspective towards safety of street food, DU journal of undergraduate research and innovation, vol- 2, issue- 2 , pp 80-90.

[2] Hill J et al (2016) Consumption patterns of street food consumers in Cape town, Journal of family ecology and consumer sciences, special edition food and nutrition challenges in Southern Africa, vol -1, ISSN-0378-5254.

[3] Atinkut $\mathrm{HB}$ et al (2018), Factors influencing consumers' choice of street foods and fast food in china, African journal of Marketing management, vol 10 (4), pp - 28-39.

[4] Sanlier N et al (2018), A study about the young consumers' consumption behaviors of street foods. http://doi.org/10.1590/1413-01232018235.17392016.

[5] Mensah P et al (2002), Street food in Accra, Ghana: how safe are they? Bulletin of the WHO, 80: (546-554).
[6] Canet C\&N'Diaye C, Street foods in Africa, Food nutrition and Agriculture, 1996; 17/18: 4-13.

[7] WHO (1996). Essential Safety requirements Street vended foods. $\mathrm{http} / / \mathrm{www}$.who.int/foodsafety/publications/streetvended-food/en/. Retrieved on march 25, 2016.

[8] KoodagiK et al, micronutrient status of street foods, J Nutr Food Sci 2013, 3: 3, doi: 10.4172/2155-9600.1000198.

[9] Byrd-Bredbenner et al (2007) Food safety self-reported behaviours and cognitions of young adults; result of a national study, Journal of food protection, 70: 91917-1926).

[10] Dr. Mishra Puja "Challenges faced by women street vendors: A case study of Ranchi district" International journal of latest technology in engineering, management and applied science, volume Vii, Issue 1, January 2018.

[11] Ma Lihua et al, "Food safety knowledge, attitude, and behaviour of street food vendors and consumer in Handan, a third tier city in China”, BMC Public health, 19: 1128 (2019).

[12] Wiatrowski $\mathrm{M}$ et al, Consumer eating behavior and opinions about the food safety street food in Poland, Nutrients (MDPI), 2021 Feb; 13 (2): 594, doi: 10.3390/nu/3020-594.

[13] Marutha K. J., Chelule P. K. Safe Food Handling Knowledge and Practices of Street Food Vendors in Polokwane Central Business District. Foods. 2020; 9: $1560 . \quad$ doi: 10.3390/foods9111560.

[14] FSSAI (2016). Food Safety and Standards Authority of India, Project clean street food. http://www.fssai.gov.in/Portals/0/Pdf/IEC Awareness Materia 1s/Leaflets/Clean_Street_Food_Brochur e.pdf Retrieved on August 29, 2016.

[15] Cope S., L. J. Frewer, 2010. Consumer perceptions of best practice in food risk communication and management: Implications for risk analysis policy. Food policy, 35. pp. 349357. 